\section{Use of contraceptive methods by sexually active teenagers in Pelotas, Rio Grande do Sul State, Brazil}

\author{
Uso de métodos anticoncepcionais em \\ adolescentes sexualmente ativos de 15 a 18 anos \\ em Pelotas, Rio Grande do Sul, Brasil
}

Clarissa Lisbôa Arla da Rocha 1

Bernardo L. Horta 2

Ricardo Tavares Pinheiro ${ }^{3}$

Ana Laura Sica Cruzeiro 3

Suelen $\mathrm{Cruz}^{3}$

\footnotetext{
${ }_{1}$ Escola de Medicina, Universidade Católica de Pelotas, Pelotas, Brasil. 2 Programa de Pós-graduação em Epidemiologia, Universidade Federal de Pelotas, Pelotas, Brasil. 3 Escola de Psicologia, Universidade Católica de Pelotas, Pelotas, Brasil.

Correspondence C. L. A. Rocha Programa de Pós-graduação em Saúde e Comportamento, Escola de Medicina, Universidade Católica de Pelotas.

Rua Almirante Barroso 1202, sala G 109, Pelotas, RS 96010-208, Brasil. nuplac@phoenix.ucpel.tche.br
}

\begin{abstract}
This study aimed to assess the prevalence of contraceptive use by adolescents. A cross-sectional study was performed from March to September 2002 in a representative sample of adolescents 15 to 18 years of age in the urban area of Pelotas, Rio Grande do Sul State, Brazil. Multiple-stage sampling was used, and in the 448 census tracts located in the urban area, 90 were sampled and households were visited in each tract. Information was collected on sexual initiation and use of contraceptive methods. Chi-square test was used to compare proportions. The sample included 960 adolescents. 88\% of subjects reported the use of any contraceptive method. Condoms were the most commonly used method (63.2\%). Low adolescent schooling was the only variable associated with increased risk of non-use of contraceptives. Condom use was higher among males, adolescents whose mothers had 9 or more years of schooling, and those reporting several sexual partners in the previous year. Condoms were the most commonly used contraceptive method.
\end{abstract}

Contraception; Adolescent; Condoms

\section{Introduction}

Adolescence is a process that occurs during the individual's evolutionary development, extending approximately from 10 to 19 years of age, characterized by a bio-psychosocial revolution, marking the transition from childhood to adulthood 1,2 .

It has been observed that sexual initiation generally occurs before the end of adolescence. In 1995, in Porto Alegre, capital of Rio Grande do Sul, the southernmost State of Brazil, mean age at first sexual intercourse was 15.5 years for girls and 13.7 for boys 1,3 . According to a study in Pelotas, another city in the same State, $45.3 \%$ of females between 15 and 19 years of age had already had sexual relations ${ }^{4}$. Early initiation of sexual activity was associated with drug use, more sexual partners, and less selectiveness towards partners 5 .

Pregnancy in this age range has shown increased incidence nearly everywhere in the world 6 . In Brazil, according to Ministry of Health data, $20.8 \%$ of pregnancies in 1994 occurred in adolescents, and by 2000 this figure increased to $26 \%$. Meanwhile, $17.5 \%$ of pregnant girls in this age bracket stated that they had wanted to become pregnant 7 .

Teenage pregnancy is associated with increased risk of low birth weight and prematurity 2 . Low birth weight, which includes not only prematurity itself (premature birth) but also intra- 
uterine growth retardation, is more common in teenage mothers 8,9 .

Other problems arising from teenage pregnancy, like increased incidence of cesarean sections and instrumental (forceps/ventouse) delivery, prolonged labor, cephalopelvic disproportion, and birth canal lacerations, have been cited in the literature, although questioned by other authors $7,10,11$.

In a study by Béria 12 in Porto Alegre, $42 \%$ of teenage schoolgirls had used condoms in their last sexual relations. A population-based study in the same city found a condom use rate of $7.5 \%$ and also showed that condom use was higher in females over 20 years of age 4,13,14.

Barreiros et al. 15, in a cross-sectional study in 2004 including 680 students in the sixth to eighth grades, who were asked about basic knowledge concerning contraceptives methods, observed that $72.8 \%$ of the adolescents reported using male condoms and $69.5 \%$ reported using oral contraceptives.

The current study thus aimed to assess the prevalence of contraceptive use in adolescents from 15 to 18 years of age in a city in the South of Brazil.

\section{Methodology}

From March to September 2002, a cross-sectional study was conducted with a representative sample of adolescents ranging from 15 to 18 years of age, living in the urban area of the city of Pelotas, Rio Grande do Sul State, Brazil.

Sampling was performed in multiple stages, based on 448 census tracts in the urban area of Pelotas. Of these tracts, 90 were randomly selected for inclusion in the study. For each sampled tract, the blocks were numbered, and next one of them was randomly selected to serve as the point of departure for visiting 86 households. After circling the block, if the interviewer had not found the necessary number of households (86), he moved to the next block, based on the numerical order of the blocks, and so on until the 86 households had been identified.

The research team visited a total of 7,740 households. All individuals from 15 to 18 years of age were interviewed in the selected households, after obtaining written informed consent from at least one parent or guardian. The interviewees completed a self-applied questionnaire on socioeconomic status, drug use, smoking, physical activity, alcohol consumption, and contraceptive use.

The study collected information from the adolescents on sexual relations and use of any contraceptive use in the previous month. Minor psychiatric disorders, smoking, obesity, religion, illicit drug use, and alcohol consumption were also evaluated. All the analyses took into account the fact that the sampling was performed in multiple stages, using the "svy" commands from Stata 9.0 (Stata Corp., College Station, U.S.A.). Comparisons of proportions used the chi-square test.

To measure social class, the study adopted the classification proposed by the Associação Brasileira de Institutos de Pesquisa de Mercado [ABIPEME; Brazilian Association of Market Research Institutes] 16, based on total household assets like TV sets, stereo systems, and motor vehicles, as well as the head-of-family's schooling. This classification divides individuals into classes A, B, C, D, and E, based on the composite scores.

\section{Results}

A total of 960 adolescents were interviewed, constituting a representative sample of the adolescents residing in the urban area of Pelotas. For 79 adolescents it was not possible to perform the interview, due either to refusal or the fact that the adolescent was not found at home after three attempts on different days and at different times. In the current article, the data analysis is limited to the 513 adolescents who reported having had sexual relations. Median age at first sexual intercourse was 15.3 years for boys and 15.9 years for girls.

Among the sexually active adolescents, $27.9 \%$ reported the pill as the contraceptive method, while $63.4 \%$ reported using condoms. Meanwhile, some $12 \%$ were not using any method to avoid pregnancy.

Table 1 shows the use of contraceptive methods by sexually active adolescents, according to socio-demographic variables. In the study sample, $13.4 \%$ of boys and $10.5 \%$ of girls did not use any contraceptive method. Contraceptive use was directly related to schooling. Adolescents with four years of schooling or fewer showed higher risk of not using any contraceptive method.

Table 2 shows that the prevalence of contraceptive use among adolescents was independent of alcohol or illicit drug use or smoking in the previous month.

Table 3 shows the use of male condoms according to socio-demographic variables. Use of male condoms was higher among boys, adolescents with more schooling, and those with higher socioeconomic status. Fewer than half of ado- 
Table 1

Use of any contraceptive method according to socio-demographic variables. Pelotas, Rio Grande do Sul State, Brazil, 2002

\begin{tabular}{|c|c|c|}
\hline Variable & Use of any contraceptive method (\%) & $\mathbf{n}$ \\
\hline Gender & $p>0.05$ & \\
\hline Male & 86.7 & 294 \\
\hline Female & 89.5 & 219 \\
\hline Adolescent's age (years) & $p>0.05$ & \\
\hline 15 & 86.2 & 65 \\
\hline 16 & 88.0 & 133 \\
\hline 17 & 86.1 & 144 \\
\hline 18 & 90.1 & 171 \\
\hline Adolescent's schooling (years) & $p<0.05$ & \\
\hline$\leq 4$ & 70.6 & 34 \\
\hline $5-8$ & 88.6 & 201 \\
\hline$\geq 9$ & 89.6 & 278 \\
\hline Social class & $p>0.05$ & \\
\hline$A$ and $B$ & 90.7 & 182 \\
\hline C & 88.3 & 197 \\
\hline $\mathrm{D}$ and $\mathrm{E}$ & 83.6 & 134 \\
\hline Maternal schooling (years) & $p>0.05$ & \\
\hline$\leq 4$ & 84.4 & 109 \\
\hline $5-8$ & 88.2 & 229 \\
\hline$\geq 9$ & 89.7 & 175 \\
\hline Paternal schooling (years) & $p>0.05$ & \\
\hline$\leq 4$ & 82.1 & 112 \\
\hline $5-8$ & 90.4 & 229 \\
\hline$\geq 9$ & 88.4 & 172 \\
\hline Total & & 513 \\
\hline
\end{tabular}

Table 2

Use of any contraceptive method, according to alcohol and drug use and smoking. Pelotas, Rio Grande do Sul State, Brazil, 2002.

\begin{tabular}{lcc}
\hline Variable & $\begin{array}{c}\text { Use of any contraceptive } \\
\text { method (\%) }\end{array}$ & $\mathbf{n}$ \\
\hline Alcohol consumption in previous month & $p>0.05$ & 278 \\
Yes & 89.6 & 234 \\
No & 85.9 & 59 \\
Illicit drug use in previous month & $p>0.05$ & 454 \\
Yes & 88.1 & 120 \\
No & 87.9 & 393 \\
Smoker & $p>0.05$ & 513 \\
Yes & 87.5 & \\
Total & 88.0 & \\
\hline
\end{tabular}


Use of male condoms, according to socio-demographic variables. Pelotas, Rio Grande do Sul State, Brazil, 2002.

\begin{tabular}{lcc}
\hline Variable & Always uses condoms (\%) & $\mathbf{n}$ \\
\hline Gender & $p<0.05$ & \\
Male & 64.3 & 283 \\
Female & 50.7 & 211 \\
Adolescent's age (years) & $p>0.05$ & 64 \\
15 & 60.9 & 128 \\
16 & 55.5 & 136 \\
17 & 61.8 & 166 \\
18 & 57.2 & 33 \\
Adolescent's schooling (years) & $p<0.05$ & 188 \\
$\leq 4$ & 36.4 & 273 \\
$5-8$ & 54.8 & 179 \\
$\geq 9$ & 63.7 & 187 \\
Social class & $p<0.05$ & 128 \\
A and B & 61.5 & 105 \\
C & 63.6 & 170 \\
D and E & 46.9 & 494 \\
Maternal schooling (years) & $p<0.05$ & 173 \\
$\leq 4$ & 45.7 & 106 \\
$5-8$ & 58.3 & 218 \\
$\geq 9$ & 66.5 & 170 \\
Paternal schooling (years) & $p>0.05$ & \\
$\leq 4$ & 52.8 & \\
$5-8$ & 56.0 & \\
$\geq 9$ & 65.3 & \\
Total & & \\
\hline
\end{tabular}

* Information on condom use was unavailable for 19 adolescents.

lescents in social classes D and E reported using male condoms in sexual relations.

Table 4 shows that the use of male condoms in the last sexual intercourse was not associated with alcohol or drug use or smoking. Meanwhile, adolescents who reported having only one sexual partner in the previous 12 months reported the lowest condom use rate in their sexual relations. This association was independent of gender, i.e., both boys and girls with fewer partners were less prone to using male condoms.

\section{Discussion}

The current study evaluated a representative sample of adolescents living in the urban area of Pelotas. The response rate was $92.4 \%$, thus reducing the possibility of a selection bias. In relation to the quality of information, the use of a selfcompleted questionnaire ensured the confidentiality of the information, thereby reducing the possibility that subjects might omit information on their sexual initiation or provide erroneous information on condom use or other contraceptive methods during sexual relations.

Prevalence of any contraceptive method among sexually active adolescents in Pelotas was $87.9 \%$. This proportion was higher than that observed by Vieira et al. 17 in a study in 1996 in the city of São Paulo, in which $63.6 \%$ of non-single women from 15 to 19 years of age reporting the use of some contraceptive method.

Use of any contraceptive was related to the adolescent's schooling. Adolescents with four years of schooling or fewer presented a higher risk of not using any contraceptive method, as compared to those with 9 years or more. Similar results have been observed in other studies $6,17,18,19,20,21$.

Male condoms were the most widely used contraceptive method in these adolescents (63.2\%), a higher rate than found in the literature, ranging from $3.2 \%$ to $22.5 \% 14,22,23,24$. 
Use of male condoms, according to alcohol and drug use, smoking, and number of sexual partners. Pelotas, Rio Grande do Sul State, Brazil, 2002

\begin{tabular}{lcc}
\hline Variable & Always uses condoms (\%) & $\mathbf{n}$ \\
\hline Alcohol consumption in previous month & $p>0.05$ & 266 \\
Yes & 62.0 & 227 \\
No & 54.2 & 58 \\
Illicit drug use in previous month & $p>0.05$ & 436 \\
Yes & 56.9 & 117 \\
No & 58.7 & 377 \\
Smoker & $p>0.05$ & 319 \\
Yes & 59.0 & 127 \\
No & 58.4 & 31 \\
Number of sexual partners in previous 12 months & $p<0.05$ & 494 * \\
1 & 54.9 & 67.7 \\
$2-4$ & 77.4 & \\
$\geq 5$ & & \\
Total & & \\
\hline
\end{tabular}

* Information on condom use was unavailable for 19 adolescents.

The condom use rate was higher in boys than in girls, consistent with other studies 12,15.

Vieira et al. 17 reported that male condoms were the most widely used method by partners of women 15 to 19 years of age $(9.1 \%)$ in general, and the groups that least used condoms were women with steady partners 4 . We also found that the adolescents viewed condoms as a contraceptive method rather than protection against STD/AIDS.

The current study reports an increase in the use of contraceptive methods, including male condoms. The factor that merits special attention is the association between condom use and schooling in adolescents. As reported in previous studies $11,15,25,26,27$, adolescents who are not attending school and those with lower socioeconomic status show lower contraceptive use, purportedly due to lack of information and difficulties in accessibility and affordability of methods. Educational AIDS prevention campaigns encouraging condom use appear to have been successful, especially among teenagers with higher socioeconomic status, but they have also increased the social inequality in STD/ AIDS prevention. Similar on-going campaigns are needed that approach the risks, the need for treatment, and the control of sexually transmitted diseases, AIDS prevention, and unplanned pregnancy.

In relation to low-income groups, further emphasis is needed on sexual education and the use of contraceptive methods, training of community-based multipliers, and mechanisms to ensure free condom distribution. The campaigns should employ accessible language. We thus believe it is possible to reverse the prevailing social inequality in STD/AIDS prevention. 


\section{Resumo}

O estudo avaliou o uso de métodos contraceptivos em adolescentes. Entre março e setembro de 2002, realizou-se um estudo transversal na zona urbana da cidade de Pelotas, Rio Grande do Sul, Brasil. A amostragem foi em múltiplos estágios, 90 dos 448 setores censitários da zona urbana de Pelotas foram sorteados e em cada setor 86 residências foram visitadas. Considerou-se a informação do adolescente sobre a prática de relações sexuais e do uso de métodos contraceptivos. Nas comparações entre as proporções utilizou-se o teste do qui-quadrado. Foram entrevistados 960 adolescentes, enquanto que para 79 não foi possível realizar a entrevista. Aproximadamente $88 \%$ dos adolescentes usavam algum método contraceptivo. O preservativo masculino foi encontrado como o método mais usado naqueles adolescentes que têm relação sexual (63,2\%). A escolaridade do adolescente foi a única variável as sociada com o uso de contraceptivos. O uso de preservativo masculino foi mais freqüente entre os meninos, aqueles cuja mãe tinha nove ou mais anos de escolaridade e naqueles com vários parceiros. O preservativo masculino é o método mais usado.

Anticoncepção; Adolescente; Preservativos

\section{References}

1. Halbe HW, Halbe AFP, Ramos LO. A saúde do adolescente. Pediatr Mod 2000; 36:133-76.

2. Kramer MS. Determinants of low birthweight: methodological assessment and meta-analysis. Bull World Health Organ 1987; 65:663-737.

3. Mathias L, Maia EM, Maia Filho E, Landi V, Kosaka S. Estudo comparativo entre primigestas adolescentes dos 18 a 25 anos. J Bras Ginecologia 1981; 91:89-92.

4. Olinto MIA, Galvão LW. Características reprodutivas de mulheres de 15 a 19 anos: estudo comparativo e planejamento de ações. Rev Saúde Pública 1999; 33:64-72.

5. Seidman SN, Mosher WD, Aral SO. Women with multiple sexual partners: United States, 1988. Am J Public Health 1992; 82:1388-94.

6. Instituto Brasileiro de Opinião Pública e Estatística. Pesquisa sobre os hábitos e atitudes dos jovens em relação ao sexo. Rio de Janeiro: Wyeth do Brasil; 2003.

\section{Contributors}

C. L. A. Rocha designed and produced the current article. B. L. Horta conducted the data analysis and supervised the author in her research. B. L. Horta and R. T. Pinheiro were the authors of the original project and overall coordinators of the study that gave rise to the current article, having supervised the fieldwork and interviews. A. L. S. Cruzeiro participated in the fieldwork and assisted with the literature review. S. Cruz participated in the fieldwork.
7. Maia Filho NL, Tedesco RP, Neder VM, Suzano CE, Pereira RT, Mathias L. Comparação entre os resultados obstétricos de adolescentes precoces e tardias após três décadas de prevenção. GO Atual 1999; 8:14-22.

8. Galletta MA, Lippi ATA, Conceição IS, Del Zotto SB, Zugaib M. Fatores relacionados à intenção de aborto em adolescentes grávidas. In: Anales del VI Congreso Latinoamericano de Obstetricia y Ginecología de la Infancia y la Adolescencia. Havana: Associação de Obstetrícia e Ginecologia do Estado de São Paulo; 1999. p. 8.

9. Tanaka ACDA. Situação da mortalidade materna no Brasil. In: Anais do Simpósio Franco-Brasileiro sobre Prevenção da Mortalidade Materna com ênfase na Gravidez na Adolescência. São Paulo: Departamento de Saúde Materno-Infantil, Faculdade de Saúde Pública, Universidade de São Paulo; 1992. p. 7-16. 
10. Yazle MEHD, Mendes MC, Patta MC, Rocha JSY, Azevedo GD, Marcolin AC. A adolescente grávida: alguns indicadores sociais. Rev Bras Ginecol Obstet 2002; 24:609-14.

11. Velho MTC, Morais EM. Gravidez na adolescência. In: Morais EN, Maud Filho F, organizadores. Medicina materna e perinatal. São Paulo: Livraria e Editora Revinter; 2000. p. 237-41.

12. Béria J. Ficar, transar. A sexualidade do adolescente em tempos de AIDS. Porto Alegre: Tomo Editorial; 1998

13. Villela W, Barbosa R. Opções contraceptivas e vivências da sexualidade: comparação entre mulheres esterilizadas e não esterilizadas em região metropolitana do Sudeste do Brasil. Rev Saúde Pública 1996; 30:452-9.

14. Almeida MC, Aquino EM, Gaffikin-Lynne MR. Uso de contracepção por adolescentes de escolas públicas na Bahia. Rev Saúde Pública 2003; 37:56675.

15. Barreiros FA, Guazzelli CAF, Moron AF. Conhecimento básico de adolescentes escolarizados sobre métodos anticoncepcionais. Adolescência \& Saúde 2005; 2:11-16.

16. Cotrim SPQ. Contato imediato com pesquisa de propaganda. São Paulo: Global, 1988.

17. Vieira EM, Biardini R, Dal Fabbro A, Rodrigues Jr AL. Características do uso de métodos anticoncepcionais no estado de São Paulo. Rev Saúde Pública 2001; 36:263-70.

18. Bem-Estar Familiar no Brasil. Macro pesquisa nacional sobre demografia e saúde, Brasil 1996. Rio de Janeiro: Bem-Estar Familiar no Brasil; 1997.

19. Costa MC; Lopes CP Souza RP, Patel BN. Sexualidade na adolescência: desenvolvimento, vivência e proposta de intervenção. J Pediatr (Rio J) 2001; 77:217-24.
20. Ramos LO. Anticoncepção na adolescência. In Halbe HW, organizador. Tratado de ginecologia. São Paulo: Editora Roca; 2000. p. 896-902.

21. Camargos AF, Polisseni F, Amaral MCMS, Lamita RM. Mudança do comportamento sexual feminino através do tempo. In: Halbe HW, organizador. Tratado de ginecologia. São Paulo: Editora Roca; 2000. p. 1888-93.

22. Herter LD, Acetta SG. Anticoncepção e gestação na Adolescência. J Pediatr (Rio J) 2001; 177 Suppl 2:170-8.

23. Brewer TH, Hasbun J, Ryan CA, Hawes SE, Martinez S, Sanchez J, et al. Migration, ethnicity and environment: HIV risk factors for women on the sugar cane plantations of the Dominican Republic. AIDS 1998; 12:1879-87.

24. De Hovitz JA, Kelly P, Feldman J, Sierra MF, Clark L, Bromberg J, et al. Sexually transmitted diseases, sexual behavior, and cocaine use in inner-city women. Am J Epidemiol 1994; 140:1125-34.

25. Guimarães AM, Vieira MJ, Palmeira JA. Informações dos adolescentes sobre métodos anticoncepcionais. Rev Latinoam Enferm 2003; 11:293-8.

26. Zerwes EP, Rocha CLA, Casanova M, Piva I, Silva S, Ruver V. Gestação na adolescência. In: Anais do 13o Congresso da Associação Médica do Rio Grande do Sul. Porto Alegre: Associação Médica do Rio Grande do Sul; 1996. p. 21.

27. Lima CP. Gravidez na adolescência. Rev AMRIGS 1995; 41:65-8.

Submitted on $22 / \mathrm{Jun} / 2005$

Final version resubmitted on 26/Feb/2007

Approved on 19/Mar/2007 